\title{
New Advances on Nutrients Recovery from Agro-Industrial and Livestock Wastes for Sustainable Farming
}

\author{
Mirko Cucina ${ }^{1, *}$ and Luca Regni ${ }^{2}$ (1) \\ 1 Gruppo Ricicla Lab., DiSAA, Università degli Studi di Milano, Via Celoria, 2-20133 Milano, Italy \\ 2 Research Unit of Arboriculture, Department of Agricultural, Food and Environmental Sciences, University of \\ Perugia, Borgo XX Giugno, 74-06121 Perugia, Italy; luca.regni@unipg.it \\ * Correspondence: mirko.cucina@unimi.it; Tel.: +39-3338579190
}

check for updates

Citation: Cucina, M.; Regni, L. New Advances on Nutrients Recovery from Agro-Industrial and Livestock Wastes for Sustainable Farming. Agronomy 2021, 11, 2308. https:// doi.org/10.3390/agronomy11112308

Received: 26 October 2021

Accepted: 8 November 2021

Published: 15 November 2021

Publisher's Note: MDPI stays neutral with regard to jurisdictional claims in published maps and institutional affiliations.

Copyright: (c) 2021 by the authors. Licensee MDPI, Basel, Switzerland. This article is an open access article distributed under the terms and conditions of the Creative Commons Attribution (CC BY) license (https:// creativecommons.org/licenses/by/ $4.0 /)$.
The world's population continues to rise, with a medium-variant forecast predicting that by 2050, the global population will have surpassed 10 billion people [1]. As a result, it is clear that there is a need for increased food production order to meet the world's expanding population as well as to meet the Sustainable Development Goals, i.e., zero Hunger, which was defined by the United Nations in 2015 [2]. Since agriculture is the primary source of food [3], improving crop yields is a top concern. Agriculture productivity has mostly been improved via the use of fertilizers in recent decades, and global demand for nitrogen, phosphate, and potassium for fertilizer usage is predicted to grow by nearly $10 \%$ from 2016 to 2022 [4]. The growing need for fertilizers raises major concerns, which are mostly about their production and the environmental impacts related to their production and use. Among the most used synthetic fertilizers, $\mathrm{N}$ and $\mathrm{P}$ are frequently obtained from nonrenewable resources that use high-cost methods $[5,6]$, and the environmental concerns associated with their usage are well documented (e.g., eutrophication, gaseous emissions) [7]. Biobased fertilizers (BBFs) have improved the sustainability of agriculture by reducing the use of non-renewable resources and the impact of agriculture on the environment [8]. Agro-industrial and animal husbandry waste might provide a sustainable supply of BBFs, which would be low-cost and ecologically beneficial. Different technologies for recovering nutrients from organic waste are available; however, they are not widely used. The primary obstacles to nutrient recovery from agro-industrial and animal waste include unfavorable waste stream features (e.g., the presence of organic contaminants), technical obstacles (i.e., obtaining sanitized products), and a lack of information about the quality and efficacy of BBFs.

In this context, the aim of this Special Issue of Agronomy, "New Advances on Nutrients Recovery from Agro-Industrial and Livestock Wastes for Sustainable Farming", was to advance knowledge on (i) the analysis of agro-industrial and livestock waste streams and potential for nutrient recovery and supply, (ii) technologies for nutrient recovery, (iii) quality of biobased fertilizers, (iv) laboratory and field assessment of biobased fertilizers, and (v) future challenges in nutrient recovery.

Five research articles have been published in this Special Issue. These research papers cover a wide variety of research areas that are related to nutrient recovery from animal and agro-industrial wastes, including process optimization and improvement, the effects of BBFs on soil fertility and plant growth, and comparison of different organic farming processes.

Process optimization is crucial to ensuring the production of high-value BBFs, and this aspect was investigated in one of the papers published in this Special Issue [9]. In this study, it was highlighted that the evolution of the compost process and compost quality was strongly related to the content of a soluble form of nitrogen (i.e., water-extractable $\mathrm{N}$, WEN) in the composting mixtures. This observation was used to propose new parameters (i.e., WEN, TOC/WEN) to optimize the composting process.

An improved vermicomposting system was proposed to treat dairy wastewater, rice, straw, and cow manure and to recover nutrients [10]. The results of this study showed that 
this can represent a feasible method for the simultaneous disposal of organic wastes, especially in poor countries, because it incurs lower costs and has a lower impact on the environment.

The effects of compost and compost-tea (CT) applications on soil fertility, plant growth, and the environment were evaluated in two research articles [11,12]. Dairy manure compost and food waste compost showed different effects on soil microbial community composition, but in both cases, the results suggested that recycled waste composts contribute to biologically based nitrogen cycling and can increase tree growth, especially within the first year after application [11]. CT application induced plant growth and defense in pepper plants against Phytophthora capsici and Rhizoctonia solani because of its relevant soluble nutrient content and microbiota richness, which provided a novel point for plant nutrition and protection in horticultural crops [12].

Finally, the results of a comparison between different BBF applications on soil in organic farming showed that the addition of organic matter improved crop yields regardless of its source [13].

This Special Issue of Agronomy, "New Advances on Nutrients Recovery from AgroIndustrial and Livestock Wastes for Sustainable Farming", contains different papers presenting new results concerning different aspects of nutrient recovery and utilization from agroindustrial and animal waste. These research papers cover a variety of biological processes that are related to nutrient recovery (i.e., composting, vermicomposting), including the evaluation of the effects of BBF applications on soil systems, plant growth, and the environment.

The Academic Editors of this Special Issue (Dr. Mirko Cucina and Dr. Luca Regni) hope that this collection of research articles will stimulate research in the field of nutrient recovery from organic waste, not only to improve knowledge but also for applications in sustainable farming.

Author Contributions: Conceptualization, M.C. and L.R.; writing-original draft preparation, M.C.; writing-review and editing, L.R. All authors have read and agreed to the published version of the manuscript.

Funding: This research received no external funding.

Conflicts of Interest: The authors declare no conflict of interest.

$\begin{array}{ll}\text { Abbreviations } \\ \text { BBFs } & \text { Biobased fertilizers } \\ \text { CT } & \text { Compost-tea } \\ \text { N } & \text { Nitrogen } \\ \text { TOC } & \text { Total Organic Carbon } \\ \text { WEN } & \text { Water-extractable Nitrogen }\end{array}$

\section{References}

1. ONU. World Population Prospects 2019: Highlights. Department of Economic and Social Affairs, Population Division. 2019. Available online: https:/ / population.un.org/wpp/Publications/Files/WPP2019_Highlights.pdf (accessed on 11 November 2021).

2. The United Nations. Take Action for the Sustainable Development Goals-United Nations Sustainable Development. United Nations Sustainable Development. 2020. Available online: https://www.un.org/sustainabledevelopment/sustainabledevelopment-goals / (accessed on 18 October 2021).

3. FAO. Food Outlook-Biannual Report on Global Food Markets. 2020. Available online: https://doi.org/10.4060/cb1993en (accessed on 18 October 2021). [CrossRef]

4. FAO. World Fertilizer Trends and Outlook to 2022. 2020. Available online: https:/ / doi.org/10.4060/ca6746en (accessed on 18 October 2021). [CrossRef]

5. Cherkasov, N.; Ibhadon, A.O.; Fitzpatrick, P. A review of the existing and alternative methods for greener nitrogen fixation. Chem. Eng. Process. 2015, 90, 24-33. [CrossRef]

6. Günther, S.; Grunert, M.; Müller, S. Overview of recent advances in phosphorus recovery for fertilizer production. Eng. Life Sci. 2018, 18, 434-439. [CrossRef] [PubMed]

7. Khan, M.N.; Mohammad, F. Eutrophication: Challenges and solutions. In Eutrophication: Causes, Consequences and Control; Springer: Dordrecht, Germany, 2014; pp. 1-15. [CrossRef] 
8. Wang, Y.; Zhu, Y.; Zhang, S.; Wang, Y. What could promote farmers to replace chemical fertilizers with organic fertilizers? J. Clean. Prod. 2018, 199, 882-890. [CrossRef]

9. Pezzolla, D.; Cucina, M.; Proietti, P.; Calisti, R.; Regni, L.; Gigliotti, G. The Use of New Parameters to Optimize the Composting Process of Different Organic Wastes. Agronomy 2021, 11, 2090. [CrossRef]

10. Liu, X.; Geng, B.; Zhu, C.; Li, L.; Francis, F. An Improved Vermicomposting System Provides More Efficient Wastewater Use of Dairy Farms Using Eisenia fetida. Agronomy 2021, 11, 833. [CrossRef]

11. Hodson, A.K.; Sayre, J.M.; Lyra, M.C.C.P.; Rodrigues, J.L.M. Influence of Recycled Waste Compost on Soil Food Webs, Nutrient Cycling and Tree Growth in a Young Almond Orchard. Agronomy 2021, 11, 1745. [CrossRef]

12. González-Hernández, A.I.; Suárez-Fernández, M.B.; Pérez-Sánchez, R.; Gómez-Sánchez, M.Á.; Morales-Corts, M.R. Compost Tea Induces Growth and Resistance against Rhizoctonia solani and Phytophthora capsici in Pepper. Agronomy 2021, 11, 781. [CrossRef]

13. Antošovský, J.; Prudil, M.; Gruber, M.; Ryant, P. Comparison of Two Different Management Practices under Organic Farming System. Agronomy 2021, 11, 1466. [CrossRef] 